Flores Flores, Nallely Natali.

Alumna del posgrado en Artes de la Universidad de Guanajuato.

\title{
Santa María del Circo (Toscana, 1998) y Zócalo (Alÿs, 1999) como espacios de resignificación.
}

\section{Santa María del Circo (Toscana, 1998) y Zócalo (Alÿs, 1999) as resignification spaces.}

\author{
TIPO DE TRABAJO: \\ Comunicación virtual. \\ PALABRAS CLAVE: \\ Espacio, semiosfera, heterotopía, Zócalo, Santa María del Circo.
}

KEY WORDS:

Space, semiosphere, heterotopia, Zócalo, Santa María del Circo.

\section{RESUMEN.}

En el presente trabajo se desarrolla una propuesta comparativa entre dos obras de distinta naturaleza: la primera de ellas es la filmación Zócalo (Francis Alÿs, 1999); y la segunda, es la novela Santa María del Circo (David Toscana, 1998). Ya que estas obras, en principio, parecen tener una serie de elementos que las emparentan. En ambas: se tratan espacios de tránsito; son registros, aunque uno imaginario y otro real, simbólicos; hay perturbación del espacio; es posible el tratamiento como semiosferas por las marcadas fronteras; entre otros aspectos que también pudiesen fungir como justificantes comparativos. Además, los espacios de ambas obras pueden ser interpretados como heterotopías, acorde con el concepto de Foucault, insertas dentro de otras heterotopías y con significaciones de amplio espectro: la ciudad, en el caso de Zócalo, y el desierto, para Santa María del Circo. Es así que teóricamente, se parte de un concepto semiótico para tratar la situación antropológica posteriormente. Con ello, se habla también de las representaciones artísticas del contexto social de finales del siglo XX y de la realidad percibida, por Alÿs y Toscana, materializada en las obras que se estudian.

\section{ABSTRACT.}

On this paper we develop a comparative approach between two art objects of different nature: first of them is film called Zócalo (Francis Alÿs, 1999); and, second of them, is Santa María del Circo novel (David Toscana, 1998). Comparison is possible due to these objecs contain some similar elements. On both of them, we find: these are transit spaces and these are ,also, symbolic registers, although novel is imaginary one and film is real one; irruption of characters on both spaces means perturbing; on both of them, we can use semiosphere concept because they keep frontiers delimited ; and so on, more motives to comparison. Besides, spaces can be interpretated according with Focault's concept of heterotopia. Also, these spaces are into other heterotopia: that is to say, Zócalo is into city of Mexico and Zócalo and any city could be read like this kind of nonplace. It is the same to Santa María del Circo, town which is into desert because desert could be a heterotopia too. So, in theory, been treated with a semiotics' concept allows to sum an anthropological interpretation. Analyzing with these concepts (semiosphere and heterotopia), allows us to talk about art's representations of social reality in the nineties of twenty century. It is not just about a written and a visual discourse, it is about how a writer and an artist perceive their reality, how they take it and how they express it out. 